\title{
The importance of work or productive activity in life care planning and case management
}

\author{
Christine Reid $^{\mathrm{a}, *}$ and Susan Riddick-Grisham ${ }^{\mathrm{b}}$ \\ ${ }^{a}$ Department of Rehabilitation Counseling, Virginia Commonwealth University, Richmond, VA, USA \\ ${ }^{\mathrm{b}}$ Life Care Manager, LLC, Richmond, VA, USA
}

\begin{abstract}
.
INTRODUCTION: The importance of work or productive activity for the well-being, community integration, and quality of life of people living with disabilities is addressed, with implications for life care planning and case management.

BACKGROUND: The role of work or productive activity in our society, and consequences of deprivation if rehabilitation services do not address vocational effects of disabilities, is explored. A continuum of productivity options is introduced; types of vocational rehabilitation assessment processes and interventions are described.

PURPOSE: The role of vocational rehabilitation services in life care planning and case management is discussed, focusing on quality of life for people living with disabilities.

CONCLUSION: Rehabilitation and health care professionals should understand the importance of work or other productive activity, and support the development of appropriate plans to address those needs among people who have disabilities.
\end{abstract}

Keywords: Rehabilitation, work, productive activity, life care planning, disability, case management, vocational, community integration, quality of life, disability

\section{Introduction}

When people have significant disabilities, the interactions between those disabilities and the environments in which people live have profound implications for quality of life. Those environments extend far beyond the home, and into the community, the workplace, and the world at large. Sander, Clark, and Pappadis (2010) identified three main areas that define community integration of people with disabilities: 1) employment or other productive activity, 2) independent living, and 3) social activity (p. 121). Araten-Bergman and Stein (2014) identified employment as important for

\footnotetext{
*Address for correspondence: Christine Reid, Department of Rehabilitation Counseling, Virginia Commonwealth University, POB 980330, Richmond, VA 23298-0330, USA. Tel.: +1 804827 0915; Fax: +1 804828 1321; E-mail: creid@vcu.edu.
}

"realizing the human rights of individuals with disabilities" (p. 381).

\section{Life care planning for people living with disability}

Life care planning is a systematic process of identifying and quantifying an individual's multidimensional disability-related needs (Deutsch \& Reid, 2003). One of those dimensions of disability-related needs is the effect on work and other productive activities. The life care planning process involves gathering information and evaluating the disability-related needs of an individual in order to project what that person will need into the future to minimize complications and maximize quality of life. It results in a life care plan document, a "roadmap" of options for the individual living with 
disability and her or his family to use to make informed decisions about those options (Reid, 2011).

\section{Role of work in our society}

Work, and earning the means to take care of one's own needs and that of one's family, is highly valued in our society. For most people, work or other productive activity is part of our identities, and gives meaning to our lives. Those who lose that part of their identity often wish to return to it. For example, Farrell (2014) described the growing practice of "unretirement" among retired individuals who choose to return to the workforce, explaining that work has emotional and psychological rewards that have "taken deep roots in our culture" (p. 23). Farrell explained how the value of work is far greater than just the income that can be derived from that work, stating that "The factory, the office, the cubicle, the retail store, and other workplaces are communities with colleagues, cubicle mates, union brothers and sisters, and fellow employees" (p. 15).

Farrell (2014) also described the reciprocally beneficial relationship between work and health, summarizing recent research results with the simple statement, "having a job itself is a force for staying healthy" (p. 43). The effects of unemployment, including not only reduced income but also reduced social interactions and sense of self-worth, could have a negative effect not just on quality of life, but also on life expectancy for people with disabilities. Robinson (2014) and Ditchman et al. (2014) summarized many studies addressing the positive effect of work on physical and mental wellbeing. Krause (2002) identified important variables that impact life expectancy, including income, access to health care, and psychosocial adaptation; these factors are associated with consequences of unemployment. According to Leahy et al. (2014), "Without a doubt, lack of employment opportunities excludes people with disabilities from full community inclusion and participation, stalls upward mobility, greatly affects their health-related quality of life, and subjective well-being" (p. 148).

\section{Effects of brain injury on work and productive activity}

Traumatic brain injury often results in "distinctive patterns of cognitive, behavioural and physical impairment which impact significantly on independent living skills and participation in work or study" (Ponsford,
2013, p. 803). According to Kolakowsky-Hayner and Kreutzer (2001), return to work after brain injury "has been limited to as little as one-third of the brain injured population, as many as ten years post injury" (p. 41). When Deutsch, Kendall, Daninhirsch, CriminoFerguson, and McCollum (2006) followed up with people who had life care plans developed because of brain injury, they expanded their definition of vocational outcomes to include return to work, supported employment, or return to school or training with the anticipation of returning to work; in their sample, about half of the group had positive vocational outcomes. Whether the focus is on paid employment, education with a goal of employment, or some other form of productive activity, Katz, Zazler, and Zafonte (2013) clarified that "Return to some sort of productive activity is an essential part of societal reintegration and life satisfaction after brain injury" (p. 7).

\section{Continuum of productivity options}

There are many varied productivity options for people who have disabilities. At one end of the continuum could be meaningful day activities, designed to get people out of the house and interacting with others, building "social capital" (Condeluci \& Fromnech, 2014; Condeluci, Ledbetter, Ortman, Fromknecht, \& DeVries, 2008). At the other extreme is competitive employment without any supports. In between are options such as the clubhouse model, sheltered work, customized employment, supported employment, and the identification of natural workplace supports.

The clubhouse model was originally designed for people living with mental illness, but was expanded by Jacobs and DeMello (1996) to work with people who had brain injuries. Jacobs (1997) explained how clubhouses are operated by and for their members. The focus is on each individual's abilities, not on disabilities. Each member establishes his or her own goals, and is encouraged by staff members to break those goals down into smaller steps that can be accomplished relatively quickly. Members share tasks necessary to run the clubhouse, and provide both social support and accountability to each other. West, Targett, Crockatt, and Wehman (2013) provided an update about contemporary use of this model.

Sheltered work is an option designed to provide employment for people with disabilities in a segregated workshop setting, designed specifically to provide an employment opportunity for them. Sometimes sheltered work is considered to be a transitional train- 
ing step before integrated employment; other times it is considered a long-term continuing employment option. There has been significant debate over time about the efficacy and appropriateness of sheltered work, compared with the supported employment model. An example of a study finding negative effects for sheltered work as a precursor to integrated (supported) employment was published by Nazarov, Golden, and von Schrader (2012).

Customized employment (Citron, et al., 2008; Gower, Rudstam, \& Young, 2014; Wehman, Targett, \& West, 2014) involves carving out or creating specific jobs within an existing employment setting. For example, suppose an employment specialist approaches a restaurant and interviews people to see what kinds of tasks they would rather not have to do. That specialist finds out that the wait staff members dislike having to wrap silverware to prepare it for placing on tables. To them, it is a boring job that usually has to be done just when they have the least time available to do it (when there is a rush of diners). The specialist then creates a job focused primarily on wrapping silverware for the entire restaurant, and trains an individual with significant intellectual disabilities to perform the job well, with pride, in that restaurant.

Supported employment is a broader term, which encompasses not just customized employment but a broad range of options for empowering people with disabilities to be employed in "real work for real pay" (Wehman, Inge, Revell, \& Brooke, 2007). In part as a response to funding limitations in many vocational rehabilitation service delivery systems, a growing emphasis in supported employment is the identification or development of "natural supports" in the workplace (West, Kregel, Hernandez, \& Hock, 1997). This approach involves identifying coworkers or other supports already existing in the workplace that can help to empower people with significant disabilities to function well in the workplace without the need for ongoing job coaches or other external assistance.

When workplaces are designed with universal accessibility in mind, many people with disabilities qualify for and are successful in competitive employment without any assistance. The range of services and supports needed to facilitate successful employment or involvement in other meaningful, productive activities varies widely from person to person.

Independent of the continuum of productivity options is the degree to which an individual is paid for his or her productivity. Although "real work for real pay" is possible for many more people with disabilities than most members of the public realize, volunteer work can also be meaningful for those who wish to pursue it. Another dimension that is independent of the continuum of productivity options is the extent to which supports are transitional versus ongoing. An individual with a significant intellectual disability might only need transitional supports to succeed in a customized employment situation (such as wrapping silverware), while a professional accountant who is deaf might need interpreter services or computer-assisted real-time captioning (CART) services for staff meetings throughout her or his career.

\section{Vocational rehabilitation interventions}

Vocational rehabilitation interventions, designed to address vocational barriers experienced by people who have disabilities, can use any of the models along the continuum of productivity options. Chan et al. (1997) described vocational rehabilitation as "a dynamic process consisting of a series of actions and activities that follow a logical, sequential progression of services related to the total needs of a person with a disability" (p. 312) and clarified that the process usually ends with successful placement of the individual in employment. Ditchman et al. (2014) noted strong empirical support for the efficacy of vocational rehabilitation interventions, including counseling, skills training, job placement, and supported employment.

The importance of career counseling interventions, and the centrality of work for individuals with disabilities, was described by Strauser (2014). He explained that the benefits of career counseling include increasing "power, social connection, and self-determination" and are not limited to "the traditional dichotomous outcomes of employed versus unemployed" (p. 8). Career counseling can be beneficial not only for people who are seeking work, but also for those interested in finding volunteer opportunities or other ways to include meaningful, productive activities in their lives. Whether with a goal of paid employment or a goal of other meaningful activity, career counseling can facilitate finding a match between the available opportunities and the needs and interests of the individual. This is important for job satisfaction; without such a match, "just any job" is not likely to meet the individual's needs. Keeping in mind that lower job satisfaction is associated with decreased mental and physical health (Fritzsche, Dhanani, \& Spencer, 2014), this is highly relevant to life care planning and case management with people who have disabilities. 
Job development and placement services can help people with disabilities find a "match" between job opportunities and their own abilities and needs. Gower et al. (2014) summarized factors that facilitate successful job placement, with a focus on understanding the needs of employers as well as the needs and assets of people with disabilities. Bissonette (1994) focused on "the art of creating opportunity" (title page) in her classic book about job development.

A job coach (who may also be called a vocational rehabilitation specialist, employment specialist, etc.) can provide "an array of supports to assist a person with a significant disability with obtaining and maintaining competitive employment in the community" (Targett \& Wehman, 2011, p. 135). Examples of such supports include on-the-job training, incorporating assistive technology, facilitating communication with coworkers, and designing compensatory memory strategies (Wehman, Targett, \& Cifu, 2006). Typically, the involvement of a job coach is most intensive in the early stage, until the worker develops the competencies and strategies needed to be successful on the job; the job coach then fades out involvement in a follow-along phase.

Other interventions that may be needed to achieve the work or other productive activity goals of people with disabilities include educational support and training, as well as assistive technology and rehabilitation engineering services. Education and training could be focused on a specific employment goal, or on a hobby or other productive activity (such as woodworking or photography). Similarly, assistive technology and rehabilitation engineering services could be related directly to work or to other meaningful activities. For example, if a person who becomes blind wants to learn woodworking skills "without chopping off any hands," both assistive technology and appropriate training would be important.

Supported employment services can incorporate job development and placement, job coaching, assistive technology, and other individualized services into one person-centered approach. Wehman et al. (2014) described a body of research supporting efficacy of the supported employment approach.

\section{Assessment processes}

Strauser, Chan, Wang, Wu, and Rahimi (2014) and Chan et al. (1997) provided overviews of vocational evaluation in rehabilitation practice, including attention to levels of vocational assessment. The first level (Screening) "typically involves one or two interviews with the client and then 2 to 3 hours of testing" (Strauser et al., 2014, p. 185). The second level (Clinical Case Study) adds to the first level information "a detailed psychosocial and vocational history and synthesizing information from other professionals" and often "conducting a transferable skills analysis to address job placement and possible vocational training" (p. 185). The third level (Vocational Evaluation), is the most comprehensive and time consuming, and adds to the previous levels tasks which are specific to the evaluee and his or her situation, including the use of work samples, situational evaluations, on the job evaluations, observations in community settings, and job analyses.

\section{Role of vocational rehabilitation in life care planning and case management}

Planning for appropriate work or other meaningful activity is an essential part of life care planning and case management with people who have significant disabilities. Studying the roles and functions of life care planners, Pomeranz, Yu, and Reid (2010) found that among the 21 themes emerging from the data collected, one was focused on vocational information. This study confirmed that one of the essential tasks of life care planners is to "Assess the need for short/long-term vocational/educational services" (p. 117).

If an individual providing life care planning or case management services doesn't have expertise in vocational rehabilitation, s/he should be able to refer to and coordinate efforts with other professionals who do have that expertise. Berens and Weed (2010) and Neulicht and Berens (2011) provided overviews of the roles of vocational rehabilitation counselors and consultants for life care planning and case management.

Historically, some life care planners and case managers have not addressed vocational or meaningful activity issues in their work with people who have disabilities, sometimes stating that this is beyond their area of expertise. This tendency may have developed in part from misunderstanding the "optional" nature of including a vocational/educational plan within a life care plan document itself. Weed and Field (2001) mentioned that this page is "optional" in a life care plan, because "Other professionals may choose to complete a narrative and a specific rehabilitation plan that focuses on vocational issues which is located in a separate document" (pp. 176 -177). To be clear: addressing vocational or meaningful 


\begin{tabular}{|c|c|c|c|c|}
\hline s & & $\begin{array}{r}\text { Life } \\
\text { Projected The }\end{array}$ & $\begin{array}{l}\text { Care Plan } \\
\text { rapeutic Modalities }\end{array}$ & \\
\hline $\mathbf{r}$ & Therapy & $\begin{array}{c}\text { Age/Year Initiated } \\
\text { through } \\
\text { Age/Year } \\
\text { Suspended }\end{array}$ & Frequency & Cost \\
\hline 1. & $\begin{array}{l}\text { RT (round trip cab fare)- } \\
\text { Home to Brain Injury } \\
\text { Clubhouse for brain injury } \\
\text { support services, } \\
\text { socialization, recreation }\end{array}$ & 56/2014-Life & $\begin{array}{l}4 \text { days/week x } 50 \\
\text { weeks/year }\end{array}$ & $\begin{array}{l}\$ 82.80 / \text { day } \\
\$ 16,560 / \text { year } \\
\$ 389,160 / \text { Life }\end{array}$ \\
\hline 1. & $\begin{array}{l}\text { RT - Home to Gator Park } \\
\text { for regular exercise }\end{array}$ & 56/2014-Life & $\begin{array}{l}4 \text { days/week x } 50 \\
\text { weeks/year }\end{array}$ & $\begin{array}{l}\$ 58.04 / \text { day } \\
\$ 11,608 / \text { year } \\
\$ 272,788 / \text { Life }\end{array}$ \\
\hline 1. & $\begin{array}{l}\text { RT - Home to General } \\
\text { Hospital for volunteer work }\end{array}$ & 56/2014-Life & $\begin{array}{l}1 \text { day/week x } 50 \\
\text { weeks/year }\end{array}$ & $\begin{array}{l}\$ 40,32 / \text { day } \\
\$ 2,016 / \text { year } \\
\$ 47,376 / \text { Life }\end{array}$ \\
\hline 1. & $\begin{array}{l}\text { RT - Home to Cannon } \\
\text { Square for brain injury } \\
\text { support group }\end{array}$ & 56/2014-Life & $\begin{array}{l}1 \text { day/week x } 50 \\
\text { weeks/year }\end{array}$ & $\begin{array}{l}\$ 98.32 / \text { day } \\
\$ 4,916 / \text { year } \\
\$ 115,526 / \text { Life }\end{array}$ \\
\hline 1. & $\begin{array}{l}\text { RT - Home to } A B C \\
\text { Hospital for brain injury } \\
\text { support group }\end{array}$ & 56/2014-Life & $\begin{array}{l}1 \text { day/month } \times 12 \\
\text { months/year }\end{array}$ & $\begin{array}{l}\$ 44.94 / \text { day } \\
\$ 539.28 / \text { year } \\
\$ 12,673.08 / \text { Life }\end{array}$ \\
\hline 1. & $\begin{array}{l}\text { RT - Home to Baptist } \\
\text { Church for church service }\end{array}$ & 56/2014-Life & $\begin{array}{l}1 \text { day/week x } 50 \\
\text { weeks/year }\end{array}$ & $\begin{array}{l}\$ 26.90 / \text { day } \\
\$ 1,345 / \text { year } \\
\$ 31,607.50 / \text { Life }\end{array}$ \\
\hline 1. & $\begin{array}{l}\text { RT - Home to Fitness } \\
\text { Center for } \\
\text { exercise/general health }\end{array}$ & 56/2014-Life & 4-5x/week x 50 weeks/year & $\begin{array}{l}\$ 50.42 / \text { day } \\
\$ 226.89 / \text { week (average) } \\
\$ 11,344.50 / \text { year } \\
\$ 266,595.75 / \text { Life }\end{array}$ \\
\hline
\end{tabular}

Fig. 1. Example of productive activity elements in a life care plan. 


\begin{tabular}{|c|c|c|c|c|}
\hline 1. & $\begin{array}{l}\text { RT- Home to Dr. Rabson's } \\
\text { office }\end{array}$ & 56/2014-Life & $4 x /$ year & $\begin{array}{l}\$ 44.86 / \text { trip } \\
\$ 179.44 / \text { year } \\
\$ 4,216.84 / \text { Life }\end{array}$ \\
\hline 2. & \begin{tabular}{|l|}
$\begin{array}{l}\text { Psychological counseling } \\
\text { appointment and transport }\end{array}$ \\
RT- home to Joseph \\
Counselor, Ph.D
\end{tabular} & 56/2014-Life & 6 visits/year & $\begin{array}{l}\$ 112.50 \text { (based on } \\
\text { average of } \$ 100- \\
\$ 125 / \text { session) } \\
\$ 675 / \text { year } \\
\$ 15,862.50 / \text { Life } \\
\$ 49.23 / \text { trip } \\
\$ 295.38 / \text { year } \\
\$ 6,941.43 / \text { Life }\end{array}$ \\
\hline & & & & $\begin{array}{l}\text { Lifetime Totals: } \\
\$ 1,617,747.09\end{array}$ \\
\hline \multicolumn{5}{|c|}{ Rationale/Comments: } \\
\hline \multicolumn{5}{|c|}{$\begin{array}{l}\text { According the State Code of Life Expectancy, Mr. Smith has } 23.5 \text { remaining years of life. } \\
\text { Mr. Smith cannot drive and relies on cabs to take him to and from all activities including grocery shopping, } \\
\text { attendance at Brain Injury Clubhouse House, brain injury support groups, recreation, exercise and volunteer } \\
\text { opportunities. He also utilizes a cab to attend counseling and physician appointments. The above list of cab } \\
\text { trips represents Mr. Smith's current utilization of the service. }\end{array}$} \\
\hline \multicolumn{5}{|c|}{ |Sources: } \\
\hline 1. & \multicolumn{4}{|c|}{$\begin{array}{l}\text { All Times Cab 888-111-2222 \& American Transport 888-444-8888 } \\
\text { Joseph Counselor, Ph.D (current provider) 888-999-0000 \& Mary T }\end{array}$} \\
\hline
\end{tabular}

Fig. 1. (Continued)

activity issues in life care planning and case management is not optional; it is an integral part of maximizing quality of life and minimizing complications for people living with disabilities. What is optional is whether costs of needed vocational rehabilitation services show up in the life care plan document or in a separate vocational analysis and rehabilitation plan.

Another problem that the authors of this article have noticed is that reports from some vocational experts do not address any vocational rehabilitation plan or mention of the need for involvement in any kind of productive activity that can significantly improve the quality of life for an evaluee living with disability. A vocational expert who simply comes to the conclusion that a person is "unemployable" and has a "total loss of earning capacity" without also addressing the need for some type of productive, meaningful activity is missing something important.

Regardless of which professional takes which role in planning with people who have disabilities to include work or other productive activity in their lives, attention to this important aspect of life is essential, and should not be ignored. As a "roadmap" of what to expect in the future and what options are available for a person living with disability to make informed choices about how to navigate that future, a life care plan should definitely address productive activity.

\section{Case example}

Examples of vocational rehabilitation interventions have been described in this article. Perhaps 
less clear are examples of other productive activities. To illustrate, the following is an example from the clinical practice of one of the authors of this article.

"Mr. Smith" is a 56 year-old male who sustained severe traumatic brain injury in 2004. Following many years of rehabilitation, he has been able to achieve a level of independence that includes living in his own home with family nearby to provide supervision and assistance as needed. He is unable to drive and relies on cab service or family for transportation to and from activities. He volunteers at a local hospital once a week. He also attends a brain injury clubhouse where he enjoys socialization with others and community outings. In order to maintain his general health and wellbeing, he exercises at a local gym. Transportation is also provided to allow him to receive ongoing supportive counseling and physician follow-up care.

Figure \#1 provides a (sanitized) page from Mr. Smith's life care plan, illustrating some of the services provided and costs of providing those services to incorporate meaningful, productive activity into his life. Many life care planners would include in their life care plans transportation for items that are considered medically necessary (such as counseling and physician follow-up care), but might miss costs for important activities such as Mr. Smith's volunteer work, participation in the brain injury clubhouse activities, and exercising at the local gym. Those activities support Mr. Smith's community integration, and greatly enhance his quality of life.

\section{Conclusion}

Attention to work or other productive activity for people with disabilities is essential, but at times missing from life care planning and case management practice. Rehabilitation and health care professionals should understand the importance of work or other productive activity, and support the development of appropriate plans to address those needs among people who have disabilities.

\section{Conflict of interest}

The authors declare no potential conflicts of interest with respect to the authorship and/or publication of this article.

\section{References}

Araten-Bergman, T., \& Stein, M. A. (2014). Employment, social capital and community participation among Israelis with disabilities. Work, 48, 381-390. Doi: 10.3233/WOR-131779

Berens, D.E., \& Weed, R.O. (2010). The role of the vocational rehabilitation counselor in life care planning. In R. O. Weed \& D. E. Berens (Eds.), Life care planning and case management handbook (3rd ed.), (pp. 41-62). Boca Raton, CRC Press.

Bissonnette, D. (1994). Beyond traditional job development: The art of creating opportunity Milt Wright \& Associates, Granada Hills. CA.

Chan, F., Reid, C., Kaskel, L., Roldan, G., Rahimi, M., \& Mpofu, E. (1997). Vocational assessment and evaluation of people with disabilities. Physical Medicine and Rehabilitation Clinics of North America, 8(2), 311-325.

Citron, T., Brooks-Lane, N., Crandell, D., Brady, K., Cooper, M., \& Revell, G. (2008). A revolution in the employment process of individuals with disabilities: Customized employment as a catalyst for system change. Journal of Vocational Rehabilitation, 28, 169-179.

Condeluci, A., \& Fromknecht, J. (2014). Social capital: The key to macro change. Lash Publishing, Youngsville, NC.

Condeluci, A., Ledbetter, M.G., Ortman, D., Fromknecht, J., \& DeFries, M. (2008). Social capital: A view from the field. Journal of Vocational Rehabilitation, 29(3), 133-139.

Deutsch, P.M., Kendall, S.L., Daninhirsch, C., Cimino-Ferguson, S., \& McCollom, P. (2006). Vocational outcomes after brain injury in a patient population evaluated for Life Care Plan reliability. NeuroRehabilitation, 21, 305-314.

Deutsch, P., \& Reid, C. (2003). Life care planning: A methodology for catastrophic disability analysis. In K. Anchor, J. Schmerling, \& J. Anchor (Eds.), The catastrophic injury handbook: Understanding vocational, economic, legal and clinical aspects of complex physical and mental trauma (pp. 118-131). Kendall/Hunt, Dubuque, IA.

Ditchman, N., Wu, M., Chan, F., Fitzgerald, S., Lin, C., \& Tu, W. (2014). Vocational rehabilitation. In D. R. Strauser (Eds.), Career development, employment, and disability in rehabilitation (pp. 343-360), Springer, New York.

Farrell, C. (2014). Unretirement: How Baby Boomers are changing the way we think about work, community, and the good life. New York: Bloomsbury Press.

Fritzsche, B.A., Dhanani, L.Y., \& Spencer, J.M. (2014). Empowerment through employment: Job satisfaction theories and research. In D. R. Strauser (Ed.), Career development, employment, and disability in rehabilitation (pp. 139-159), Springer, New York.

Gower, W.S., Rudstam, H., \& Young, J. (2014). Elements of effective job placement: Environmental context, employer relationships, and understanding the job seeker. In D. R. Strauser (Ed.), Career development, employment, and disability in rehabilitation (pp. 297-324), Springer, New York.

Jacobs, H.E. (1997). The Clubhouse: Addressing work-related behavioral challenges through a supportive social community. Journal of Head Trauma Rehabilitation, 12(5), 14 - 27.

Jacobs, H.E., \& DeMello, C. (1996). The Clubhouse model and employment following brain injury. Journal of Vocational Rehabilitation, 7, 169-179. 
Katz, D.I., Zazler, N.D., \& Zafonte, R.D. (2013). Clinical continuum of care and natural history. In N. D. Zazler, D., I. Katz, R. \& D. Zafonte (Eds.) Brain injury medicine: Principles and practice (2nd ed.), (pp. 2-12). Demos, New York.

Kolakowsky-Hayner, S.A., \& Kreutzer, J.S. (2001). Return to work after brain injury: A self- directed approach. NeuroRehabilitation, $16,41-47$.

Krauss, J.S. (2002). Accuracy of life expectancy estimates in life care plans: Consideration of nonbiographical and noninjury factors. Topics in Spinal Cord Injury Rehabilitation, 7(4), 59-68.

Leahy, M.J., Chan, F., Lui, J., Rosenthal, D., Tansey, T., Wehman, P., Kundu, M., Dutta, A., Anderson, C.A., Del Valle, R., Sherman, S., \& Menz, F.E. (2014). An analysis of evidence-based best practices in the public vocational rehabilitation program: Gaps, future directions, and recommended steps to move forward. Journal of Vocational Rehabilitation, 41, 147-163.

Neulicht, A.T., \& Berens, D.E. (2011). The role of the vocational rehabilitation consultant in life care planning. In S. Riddick-Grisham \& L., M. Deming (Eds.), Pediatric life care planning and case management (2nd ed.), (pp. 275-318) Boca Raton, CRC Press.

Nazarov, Z.E., Golden, T.P., \& von Schrader, S. (2012). Prevocational services and supported employment wages. Journal of Vocational Rehabilitation, 37, 119-129. Doi: 10.3233/JVR-2012-0605

Pomeranz, J.L., Yu, N.S., \& Reid, C. (2010). Role and function study of life care planners. Journal of Life Care Planning, 9(3), 57-118.

Ponsford, J. (2013). Factors contributing to outcome following traumatic brain injury. NeuroRehabilitation, 32, 803-815. Doi: $10.3233 / \mathrm{NRE}-130904$

Reid, C. (2011). Life care planning, Entry in J. S. Kreutzer, J. DeLuca, \& B. Caplan (Eds.), Encyclopedia of clinical neuropsychology (pp. 1463-1464). Springer, New York.

Robinson, R. (2014). Introduction to vocational rehabilitation. In: R. Robinson (Eds.), Foundations of forensic vocational rehabilitation (pp. 1-12). Springer, New York.

Sander, A.M., Clark, A., \& Pappadis, M.R. (2010). What is community integration anyway? Defining meaning following traumatic brain injury. Journal of Head Trauma Rehabilitation, 25(2), 121-127. Doi: 10.1097/HTR.0b013e3181cd1635

Strauser, D.R. (2014). Introduction to the centrality of work for individuals with disabilities. In: D. R., Strauser (Ed.), Career development, employment, and disability in rehabilitation (pp. 1-10). Springer, New York.

Strauser, D.R., Chan, F., Wang, M., Wu, M., \& Rahimi, M. (2014). Vocational evaluation in rehabilitation. In D. R. Strauser (Eds.), Career development, employment, and disability in rehabilitation (pp. 179-192), Springer, New York.

Targett, P.S., \& Wehman, P.H. (2011). Employment: Community based choices Paul Brooks, In P. S. Wehman (ed). Essentials of transition planning (p. 127-144). Baltimore, MD.

Weed, R.O., \& Field, T.F. (2001). Rehabilitation Consultant's Handbook (revised edition). Elliott \& Fitzpatrick, Athens, GA.

Wehman, P., Inge, K.J., Revell, W.G., \& Brooke, V.A. (2007). Real work for real pay. Paul Brookes Publishing, Baltimore, MD.

Wehman, P. H., Targett, P. S., \& Cifu, D. X. (2006). Job coaches: A workplace support. American Journal of Physical Medicine \& Rehabilitation, 85(8), 704. Doi: 10.1097/01.phm.0000228557. 69308.15

Wehman, P. H., Targett, P. S., \& West, M. D. (2014). Supported employment/customized employment. In D. R. Strauser (Eds.), Career development, employment, and disability in rehabilitation (pp. 325-342), Springer, New York.

West, M.D., Kregel, J., Hernandez, A., \& Hock, T. (1997). Everybody's doing it: A national study of the use of natural supports in supported employment. Focus on Autism and Other Developmental Disabilities, 12(3), 175-181.

West, M.D., Targett, P.S., Crockatt, S.Y., \& Wehman, P.H. (2013). Return to work following traumatic brain injury. In N. D. Zazler, D. I. Katz, \& R. D. Zafonte (Eds.), Brain injury medicine: Principles and practice (2nd ed.), (pp. 1349-1359), Demos, New York. 